\title{
Chemical Characterization of Tomato Industry Wastewater, Florida, United States
}

\author{
Maninder K. Chahal, Gurpal S. Toor, Bielinski M. Santos \\ Soil and Water Quality Laboratory, Gulf Coast Research and Education Center, \\ University of Florida, Wimauma, Florida, USA \\ Email: gstoor@ufl.edu
}

Received January 11, 2012; revised February 1, 2012; accepted March 3, 2012

\begin{abstract}
Tomato packers often struggle to find ways to reuse the large volumes of wastewater generated during the tomato cleaning and sanitizing processes due to high transportation costs for off-site disposal and strict surface water discharge regulations in Florida. Information about the composition of tomato packinghouse wastewater and the likely sources of major wastewater constituents might provide insights to develop environmentally sustainable practices for wastewater reuse. The objective of this study was to characterize the chemical composition of wastewater generated in tomato packinghouses. The wastewater samples were collected for 6 to 8 hours from dump tanks of two representative packinghouses at 30 minute intervals after start-up of packing operations during May-June 2009. Results showed that wastewater had high electrical conductivity $\left(1.3-2.8 \mathrm{dS} \cdot \mathrm{m}^{-1}\right)$ and chloride $\left(255-1125 \mathrm{mg} \cdot \mathrm{L}^{-1}\right)$ due to the use of chlorine as a sanitizer in the packinghouses. Concentrations of total phosphorus $\left(\mathrm{P}, 2.8-5.7 \mathrm{mg} \cdot \mathrm{L}^{-1}\right)$ and copper $(\mathrm{Cu}, 1.9$ $2.2 \mathrm{mg} \cdot \mathrm{L}^{-1}$ ) in wastewater were elevated due to tomato cleaning and sanitizing. To reduce $\mathrm{P}$ and $\mathrm{Cu}$ concentrations, treatment or blending of wastewater may be needed before discharging wastewater to surface waters. Concentrations of $\mathrm{P}$, potassium, calcium, magnesium, zinc, iron, and manganese were much higher in packinghouse 1 as compared to packinghouse 2 wastewater, probably due to the greater contact time of tomatoes with the dump tank water. Whereas concentrations of $\mathrm{Cu}$ were similar in both packinghouses wastewater. Greater concentrations of chemical constituents in the wastewater suggest that residues of pesticides, insecticides, and/or foliar-applied micronutrients on tomatoes may be the likely external sources of most constituents (especially $\mathrm{P}, \mathrm{Cu}$, and $\mathrm{Zn}$ ) in wastewater.
\end{abstract}

Keywords: Tomatoes; Wastewater; Packinghouse; Nutrients; Trace Metals

\section{Introduction}

Population growth and limited water resources have led to the practice of reusing domestic wastewater to meet irrigation needs of urban, agricultural, and industrial sectors in many US states, especially in Florida, California, Texas, and Arizona. Florida is recognized as a national leader in domestic wastewater reuse, boasting more than 3400 Florida Department of Environmental Protection (FDEP) permitted wastewater facilities (61\% domestic, 39\% industrial). These facilities reclaim wastewater for a wide range of beneficial purposes such as landscape and agricultural irrigation, groundwater recharge, and industrial uses [1]. However, reuse of wastewater presents a number of environmental and technical challenges. For instance, high biological oxygen demand, high total soluble solids, and toxic chemical residues present in industrial wastewater require specialized treatments [2]. Wastewater generated by 640 food processing plants (e.g. tomato canning, meat packing, wine production, dairy processing) in California's Central Valley is typically high in organic carbon, nitrogen $(\mathrm{N})$, iron $(\mathrm{Fe})$ and manganese $(\mathrm{Mn})$ sulfates [3] requiring treatment before reuse. Similarly, wastewater from swine lagoon facilities has high levels of nutrients, particularly N (472 $\left.\mathrm{mg} \cdot \mathrm{L}^{-1}\right)$ and $\mathrm{P}\left(61 \mathrm{mg} \cdot \mathrm{L}^{-1}\right)$, which require biological and chemical treatments [4].

The sources of contaminants in wastewater vary greatly among industries, and are the result of a combination of external and internal factors. For example, commonly reported sources of copper (Cu) and zinc (Zn) in the domestic wastewater are pesticide residues, pipe corrosion, wood preservatives, anti-fouling paints, and cosmetics [5]. However, information about the chemical composition and the likely sources of chemical constituents in many food processing wastewaters, especially in tomato packinghouse wastewater is not available in scientific literature.

There are approximately 70 tomato packinghouses in Florida that pack fresh-market tomatoes [6]. However, recent informal surveys among growers indicated that 
fewer than ten of those packinghouses process about $90 \%$ of the total tomato volume produced in Florida. Packinghouses use freshwater from a municipal supply and add chlorine sanitizers in dump tanks to rinse, wash, and sanitize field-harvested tomatoes before packing each day. The amount of water required depends on the type of tomato packed. For instance, the amount of water used for cleaning round tomatoes typically ranges from 3000 to 22,000 gal day $^{-1}$ while roma and grape tomatoes require 70 to 25,000 gal $\cdot$ day $^{-1}$ [6]. This water is continuously recirculated in the dump tanks and drained at end of the day (hereafter, referred to as wastewater). The quantity of wastewater generated by Florida tomato packinghouses is approximately 31.3 million gal per season [6], which needs to be handled in an environmentally sustainable way.

Wastewater produced in tomato packinghouses may contain nutrients and metals washed from tomatoes as well as metals leached from dump tanks. Elevated concentrations of elements, especially $\mathrm{P}$ and $\mathrm{Cu}$, may restrict wastewater use in the environment due to strict discharge regulations in Florida $[7,8]$. It has been suggested that water kept stagnant for long periods (24 - $48 \mathrm{~h}$ ) in a tank may leach metals such as $\mathrm{Cu}$ and $\mathrm{Zn}$ from pipes [9]. Similarly, at low $\mathrm{pH}$, halogens such as chloride $(\mathrm{Cl})$ can penetrate the chromium (Cr) oxide rust-protective coating of stainless steel tanks, commonly used in packinghouses, which contains 10 to $12 \% \mathrm{Cr}$ and $<2 \%$ nickel (Ni) thereby causing corrosion and release of $\mathrm{Cr}$ and $\mathrm{Ni}$ in the water [10-12]. However, tomato packinghouses in Florida maintain $\mathrm{pH}$ in the neutral range, which can effectively reduce the potential for $\mathrm{Cr}$ and $\mathrm{Ni}$ leaching from stainless steel to wastewater. Knowledge of the chemical composition of wastewater produced in tomato packinghouses and the sources of chemical constituents in the dump tanks can help develop solutions to sustainably manage wastewater in Florida. Therefore, the objective of this study was to characterize the potential accumulation of chemical constituents in tomato packinghouse wastewater.

\section{Materials and Methods}

\subsection{Tomato Packing Operations in Packinghouses}

In west-central Florida, there are two major tomato growing seasons: July-Dec and Jan-Apr [13]. During each season, tomatoes are picked in two harvests, usually 10 - 12 weeks after planting; packing of tomatoes continues for about 4 - 8 weeks after the start of harvesting. Field-harvested tomatoes are transported to the packinghouses, where the tomatoes are washed and sanitized before packing. The tomatoes are first dumped into a water flume system (hereafter, referred to as dump tanks).
The rate at which tomatoes are added to the dump tanks drives the flow of tomatoes through the packing line. Each day, the dumping rate is adjusted to accommodate the degree of sorting and grading required at the packing counter. To avoid cross-contamination with pathogens during washing in the recirculated dump tank water, sanitizers such as chlorine gas, are constantly added to the water to maintain free chlorine levels in the dump tank at $150-200 \mathrm{mg} \cdot \mathrm{L}^{-1}$ in water at a $\mathrm{pH}$ of 6.5 to 7.5 [14]. The daily packing operation typically lasts for 6 to 8 hours.

\subsection{Wastewater Sample Collection}

Wastewater samples were collected from two representative tomato packinghouses (hereafter, referred to PKG 1 and PKG 2) during May-June 2009; the packing season for tomatoes grown in Jan-Apr 2009. PKG 1 used chlorine gas $\left(\mathrm{Cl}_{2}\right)$ and PKG 2 used chlorine dioxide $\left(\mathrm{ClO}_{2}\right.$, Selectrocide 12 G, $500 \mathrm{ppm}$ ) as a sanitizer in the dump tanks. In both packinghouses, typical operational time of tomato packing lines varied from 6 (PKG 2) to 8 (PKG 1) hours. Daily operational hours in packinghouses varied due to the amount of tomatoes packed. In addition, variation in the size and quality of different lots of tomatoes from different growers also altered the flow time. For each of the two packinghouses, four sampling events were conducted at weekly intervals during May-June 2009. During each sampling event, water samples were collected from the dump tanks in $250 \mathrm{~mL}$ plastic bottles before the beginning of packing operation. After the start of packing operation, wastewater samples were collected from the dump tanks at 30 minute intervals throughout daily operation (6 to $8 \mathrm{~h}$ ). The collected samples were chilled on ice, brought to the laboratory, and analyzed for $\mathrm{pH}, \mathrm{EC}, \mathrm{Cl}, \mathrm{P}$, and trace metals. The amount of tomatoes washed in 30 minute intervals was calculated based on the rate of dumping i.e. time taken to wash a given amount of tomatoes, say $1000 \mathrm{~kg}$.

Amount of tomatoes washed $(\mathrm{kg})=$ Time interval $(30$ minutes)/Rate of dumping (minutes per $1000 \mathrm{~kg}$ of tomatoes)

\subsection{Laboratory Analysis}

Approximately $100 \mathrm{~mL}$ of each collected wastewater sample was preserved with concentrated $\mathrm{H}_{2} \mathrm{SO}_{4}(\sim 1 \mathrm{ml})$ at $\mathrm{pH}<2$ and stored at $4^{\circ} \mathrm{C}$ before analysis for total $\mathrm{P}$ and trace metals. Another $150 \mathrm{~mL}$ of unpreserved sample was shelved and allowed to acclimate to room temperature before measuring $\mathrm{pH}$ and electrical conductivity (EC) using a digital meter (Accumet XL 60, dual channel $\mathrm{pH} /$ ion/conductivity/dissolved oxygen meter, Fisher Scientific, Pandan Crescent, Singapore). Chloride in unpreserved samples was determined using a discrete analyzer 
(AQ2 $^{+}$, Seal Analytical Inc, Mequon, WI). Preserved wastewater samples were analyzed for total $\mathrm{P}$ and 18 metals including aluminum (Al), arsenic (As), boron (B), calcium (Ca), cadmium (Cd), cobalt (Co), chromium (Cr), copper $(\mathrm{Cu})$, iron $(\mathrm{Fe})$, potassium $(\mathrm{K})$, magnesium $(\mathrm{Mg})$, manganese $(\mathrm{Mn})$, molybdenum (Mo), sodium (Na), nickel (Ni), lead $(\mathrm{Pb})$, selenium (Se), and zinc ( $\mathrm{Zn})$ on an inductively coupled plasma-optical emission spectrometer (ICP-OES; PerkinElmer Optima 2100 DV; PerkinElmer, Shelton, CT) using an EPA approved method [15]. Among these trace metals, 11 were not detected (Al, As, $\mathrm{B}, \mathrm{Cd}, \mathrm{Co}, \mathrm{Cr}, \mathrm{Mo}, \mathrm{Mn}, \mathrm{Ni}, \mathrm{Pb}$, and $\mathrm{Se}$ ) in any wastewater sample and therefore are not reported. For trace metals such as $\mathrm{Cr}$ and $\mathrm{Ni}$, the detection limits were 0.02 and $0.1 \mathrm{mg} \cdot \mathrm{L}^{-1}$, respectively.

\subsection{Statistical Analysis}

Mean, standard deviation, and range for the concentration of different parameters in wastewater samples were calculated in Microsoft Excel 2007. A correlation matrix was used to evaluate the significance of relationships between the different constituents at 0.05 probability level using the DATA analysis program in Microsoft Excel. Simple and stepwise linear regression was performed using Statistix (Statistix Analytical Software, version 8, Tallahassee, FL) with LINEAR MODELS procedures.

\section{Results and Discussion}

\subsection{Amount of Tomatoes Washed in the Packinghouses}

During four sampling events, approximately 305 tons $\left(10^{3} \mathrm{~kg}\right)$ of tomatoes were washed in $8 \mathrm{~h}$ in PKG 1 , while 287 tons of tomatoes were washed in $6 \mathrm{~h}$ in PKG 2 (Figure 1). In PKG 1, most of the tomatoes washed during the first $6 \mathrm{~h}$ of operation were roma tomatoes (range of weight: 102 - $121 \mathrm{~g}$ ), followed by 1 - $2 \mathrm{~h}$ washing of round tomatoes (range of weight: 170 - 252 g) [16,17]. In PKG 2, only round tomatoes were packed all day. The variability in tomato types (and sizes) resulted in different flow times in dump tanks. For example, approximately $454 \mathrm{~kg}$ of tomatoes moved through the dump tanks every 55 - 72 seconds in PKG 1 (roma) and 29 - 40 seconds in PKG 2 (round). This resulted in greater contact time of roma tomatoes that had more surface area due to small size with dump tank water in PKG 1 as compared to PKG 2 that packed round tomatoes with larger size and lower surface area.

\subsection{Chemical Characteristics of Municipal Water Used in Packinghouses}

Municipal water was used in the dump tanks of both

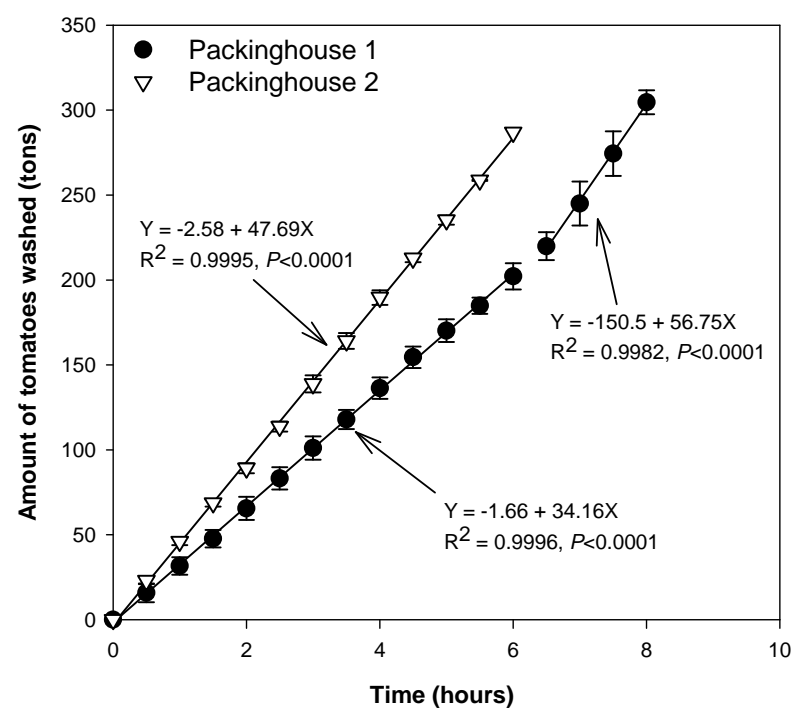

Figure 1. Mean ( $\mathrm{n}=\mathbf{4}$ for each packinghouse) cumulative amount of washed tomatoes with time during May-June 2009. Error bars indicate standard deviation. Packinghouse 1 packed roma tomatoes for 6 hours followed by round tomatoes for 2 hours. Packinghouse 2 only packed round tomatoes.

packinghouses to wash and sanitize tomatoes. Both packinghouses were located in close proximity to each other and shared a municipal water source. As a result, the $\mathrm{pH}$ (7.1 - 7.2), EC $\left(0.38-0.43 \mathrm{dS} \cdot \mathrm{m}^{-1}\right)$, and concentration of all chemical constituents, including $\mathrm{Cl}, \mathrm{P}, \mathrm{Ca}, \mathrm{Mg}, \mathrm{K}, \mathrm{Cu}$, Fe, and $\mathrm{Zn}$ were similar in both packinghouses municipal water.

\subsection{Wastewater EC and Chloride}

Chloride concentrations and EC in wastewater continuously increased as more tomatoes were washed (Figure 2). However, the magnitude of $\mathrm{EC}$ and $\mathrm{Cl}$ increase was much greater in PKG 1 (higher slope) than PKG 2 (lower slope). For instance, in PKG 1, mean $\mathrm{EC}$ and $\mathrm{Cl}$ in four sampling events was $0.4 \mathrm{dS} \cdot \mathrm{m}^{-1}$ and $24 \mathrm{mg} \cdot \mathrm{L}^{-1}$ before washing, which increased to $1.3 \mathrm{dS} \cdot \mathrm{m}^{-1}$ and $>400 \mathrm{mg} \cdot \mathrm{L}^{-1}$ after washing 50 tons of tomatoes, respectively. In contrast, EC and $\mathrm{Cl}$ were $0.72 \mathrm{dS} \cdot \mathrm{m}^{-1}$ and $107 \mathrm{mg} \cdot \mathrm{L}^{-1}$ in PKG 2 wastewater after washing 50 tons of tomatoes. This increase in EC and $\mathrm{Cl}$ in both packinghouses was attributed to the use of sanitizers such as chlorine gas in PKG 1 and chlorine dioxide in PKG 2 dump tanks. Overall, EC and Cl trends showed much less variability among four sampling events in PKG 2 as compared to PKG 1 as can be seen from standard error bars in Figure 2. This finding may be due to more controlled conditions in PKG 2 than in PKG 1. For instance, in PKG 1, chlorine gas was manually injected from pressurized gas cylinders based on chlorine, $\mathrm{pH}$, and oxidation-reduction potential measurement in dump tanks. 

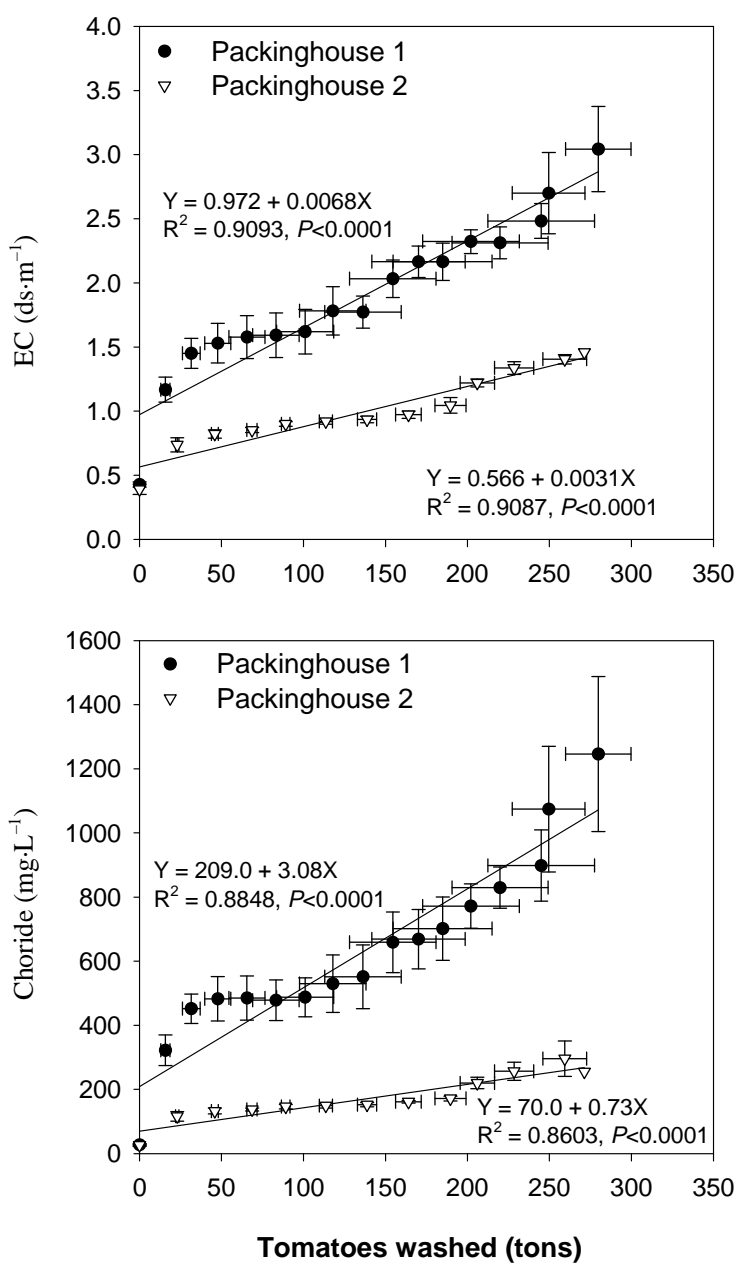

Figure 2. Effect of cumulative amounts of washed tomatoes on mean ( $n=4$ for each packinghouse) wastewater EC and chloride during May-June 2009. Bi-directional error bars indicate standard error of the mean.

However, in PKG 2, chlorine dioxide addition was automated in the dump tanks. Other factors that may have caused greater variability and greater concentration of EC and $\mathrm{Cl}$ in PKG 1 wastewater may include: 1) more breaks or stops during the packing operation due to technical problems in the dumping machine; 2) crowding of tomatoes at the packing counter that slowed the packing operation; and 3) shifting of tomatoes from small-sized roma to large-sized round. These factors resulted in greater flow time and more contact time of tomatoes in the dump tanks. It is important to note that the previous study [18] has shown that levels of total hetrotrophic bacteria were lower and similar in both packinghouses wastewater despite a much higher $\mathrm{Cl}$ concentration in PKG 1 than PKG 2, suggesting that these $\mathrm{Cl}$ levels were effective in killing microbes and that chlorine use in the packinghouse may be reduced. The regular monitoring of EC in dump tanks will aid in determining when EC approaches high values so that chlorine use can be curtailed, which, in turn, will reduce operating costs and reduce $\mathrm{Cl}$ and EC in the resulting wastewater.

\subsection{Wastewater Chemical Constituents}

The primary constituents that enter into the dump tanks are those present in the freshwater source, the chlorine sanitizers used in the dump tanks, and those carried from the field with harvested tomatoes (such as residues on tomatoes). As the levels of these constituents were minimal in the freshwater source, the only thing accounting for increase in the concentration of $\mathrm{P}, \mathrm{Cu}, \mathrm{Zn}$, $\mathrm{Fe}$ (Figure 3) and Ca, Mg, K (Figure 4) in wastewater is the amount of tomatoes washed. In the two packinghouses, a significant relation $\left(\mathrm{R}^{2}=0.90-0.98, P<\right.$ 0.0001 ) between amounts of washed tomatoes and wastewater constituents (except lower $\mathrm{R}^{2}$ of 0.55 for $\mathrm{Zn}$ in PKG 2) indicates that the amount of tomatoes washed (external factor) are likely the major sources of $\mathrm{P}, \mathrm{Cu}, \mathrm{Zn}$, $\mathrm{Fe}, \mathrm{Ca}, \mathrm{Mg}$, and $\mathrm{K}$ in the wastewater (Figures 3-4).

Similar to $\mathrm{Cl}$ and EC increase in wastewater, concentrations of $\mathrm{P}, \mathrm{Zn}, \mathrm{Fe}, \mathrm{Mg}$, and $\mathrm{K}$ were elevated and more variable in PKG 1 than in PKG 2; whereas the variability and magnitude (similar slope of 0.0081 ) of $\mathrm{Cu}$ increase was similar in both packinghouses. Overall, a greater contact time (55 - 72 seconds) of small-sized roma tomatoes (with higher surface area) in PKG 1 dump tank compared with lower contact time (29 - 40 seconds) of large-sized round tomatoes (with lower surface area) in PKG 2 dump tank probably resulted in greater concentrations of all constituents (except $\mathrm{Cu}$ ) in PKG 1 than PKG 2 wastewater.

In Florida, a variety of organophosphate insecticides, containing $\mathrm{P}$, with active ingredients such as dimethoate, malathion, and methamidophos are foliarly applied on the tomato crop to control aphids, mites, white flies, and fruitworms [13]. Stevens and Kilmer [19] reported that $52 \%$ of field-grown tomatoes contained residues of methamidophos, with concentrations up to $0.56 \mathrm{mg} \cdot \mathrm{L}^{-1}$. Similarly, foliar applied fungicides containing mono and di-K salts of phosphorous acid to control powdery mildew and Phytopthora species may also leave residues on the tomato fruits and foliage (leaves, stems) which may act as sources of $\mathrm{P}$ and $\mathrm{K}$ in the wastewater. The $\mathrm{Cu}$ based fungicides ( $\mathrm{Cu}$ hydroxide or $\mathrm{Cu}$ sulfate as active ingedients) are frequently used in foliar applications in tomato production against bacterial spot, anthracnose, and early blight, and are sometimes applied 1 - 2 days before harvesting [13]. The foliar application of fungicides containing Zn salts (e.g. Mancozeb and Ziram) against anthracnose, early blight, and grey leaf spot may be another source of $\mathrm{Zn}$ residues to the wastewater. In addition, residues of foliar-applied $\mathrm{Cu}$ and $\mathrm{Zn}$ as micronutrients may also be a likely source of wastewater $\mathrm{Cu}$ and $\mathrm{Zn}$. 

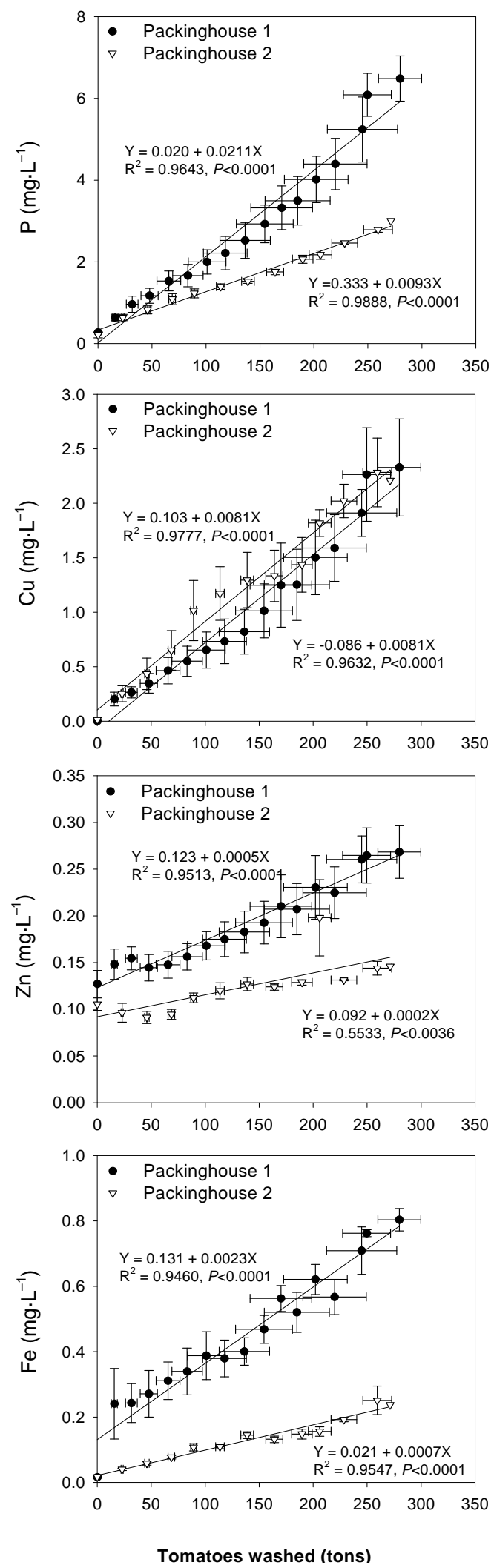

Figure 3. Effect of cumulative amounts of washed tomatoes on mean ( $n=4$ for each packinghouse) wastewater $P, C u$, $\mathrm{Zn}$, and Fe concentrations during May-June 2009. Bi-directional error bars indicate standard error of the mean.
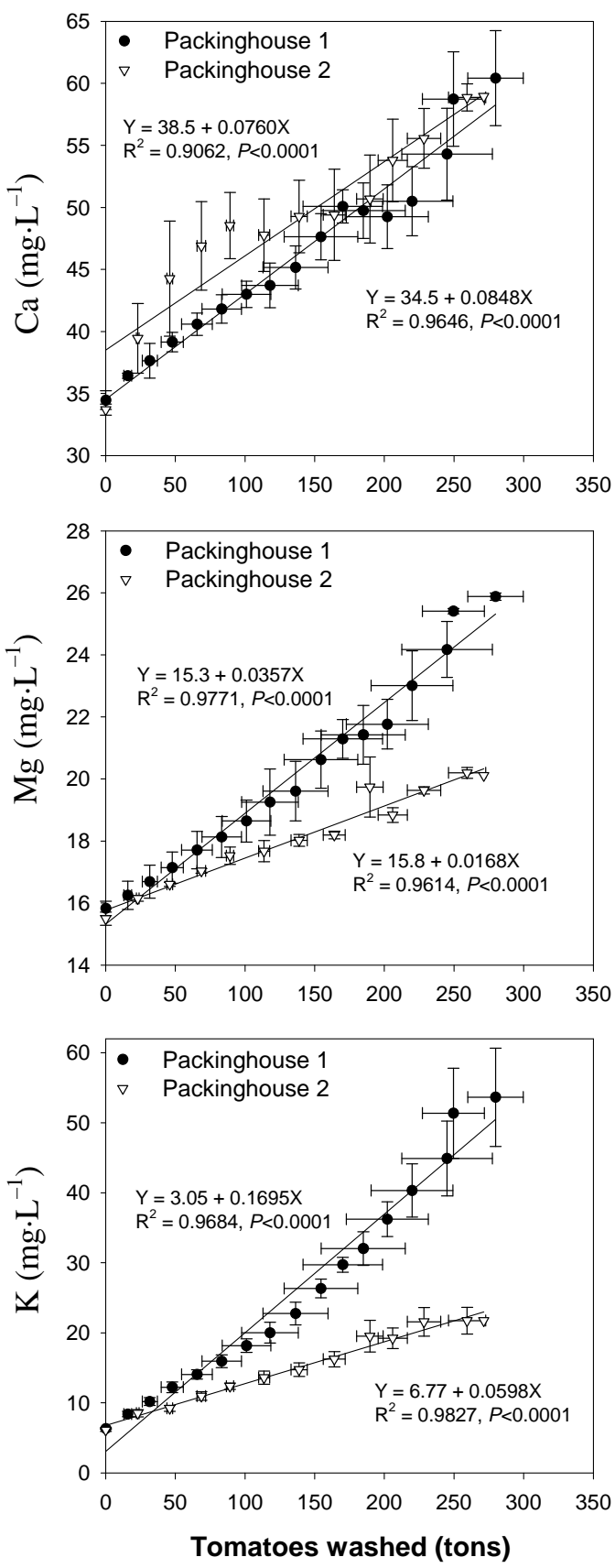

Figure 4. Effect of cumulative amounts of washed tomatoes on mean ( $\mathrm{n}=4$ for each packinghouse) wastewater $\mathrm{Ca}, \mathrm{Mg}$, and $K$ concentrations during May-June 2009. Bi-directional error bars indicate standard error of the mean.

\subsection{Implications of Using Packinghouse Wastewater in the Environment}

According to FDEP rule 62-660.805 [7], an industrial wastewater discharge permit is required if wastewater volume is between 19,000 and 190,000 L.day ${ }^{-1}$. Wastewater generation of less than $19,000 \mathrm{~L} \cdot \mathrm{day}^{-1}$ is exempted from the requirement of permit provided that the wastewater meets all surface water quality standards. Several 
of the Florida packinghouses generate more than 19,000 $\mathrm{L}$ of wastewater day ${ }^{-1}$ [6]. The chemical composition of wastewater at the end of the packing operation showed elevated concentrations of all elements, but the magnitude of increase was much greater for some elements $(\mathrm{Cl}$, $\mathrm{EC}, \mathrm{P}, \mathrm{Cu}$ ). Wastewater $\mathrm{pH}$ was maintained in the neutral range (6.5 - 8) as recommended for Florida packinghouse dump tanks [14]; therefore the wastewater is suitable for irrigating most crops without any adverse $\mathrm{pH}$ effects on crop and soil properties [20]. The $\mathrm{pH}$ is also in the recommended range for Florida class IV agricultural water use [7]. However, the EC in final wastewater was greater in PKG $1\left(2.8 \mathrm{dS} \cdot \mathrm{m}^{-1}\right)$ than PKG $2\left(1.3 \mathrm{dS} \cdot \mathrm{m}^{-1}\right)$ due to higher $\mathrm{Cl}$ in PKG 1 (1125 mg. $\mathrm{L}^{-1}$ ) compared with PKG 2 $\left(255 \mathrm{mg} \cdot \mathrm{L}^{-1}\right.$ ). The high EC values found in PKG 1 wastewater should be interpreted as having slight to moderate irrigation restrictions for salt sensitive crops such as strawberry, onions, and beans [20]. Significant correlation of EC with $\mathrm{Cl}$ in this study $(\mathrm{r}=0.95)$ indicated that chlorine use in packinghouses increased EC in wastewater. According to Bartz et al. [14], when chlorine gas $\left(\mathrm{Cl}_{2}\right)$ is dissolved in water, it readily forms hypochlorous acid ( $\mathrm{HOCl})$ and hypochlorite ion $\left(\mathrm{OCl}^{-}\right)$. Thus, three forms of chlorine $\left(\mathrm{Cl}_{2}, \mathrm{HOCl}\right.$, and $\left.\mathrm{OCl}^{-}\right)$are present in aqueous chlorine solution which readily oxidizes organic compounds with different redox potentials and generate $\mathrm{Cl}$ ions in the solution [21]. Our previous study [18] in these two packinghouses found that microbe levels in dump tank water were lower and similar; therefore, it seems intuitive that any reduction in the use of chlorine sanitizers will substantially reduce wastewater EC. For example, EC was $2.8 \mathrm{dS} \cdot \mathrm{m}^{-1}$ in PKG 1 and $1.3 \mathrm{dS} \cdot \mathrm{m}^{-1}$ in PKG 2. The EC levels in wastewater can be reduced by blending wastewater with higher-quality water (groundwater, municipal water) before using as an irrigation source for the salt sensitive crops. As a comparison, EC in our wastewater was lower than dairy wastewater $\left(3.1 \mathrm{dS} \cdot \mathrm{m}^{-1}\right)$ and poultry lagoon wastewater $\left(7.9 \mathrm{dS} \cdot \mathrm{m}^{-1}\right)$ [22].

All chemical constituents showed a greater magnitude of increase in PKG 1 wastewater than PKG 2 due to greater contact time of the tomatoes (with high surface area) with water, which was 55 - 72 seconds in PKG 1 and 29 - 40 seconds in PKG 2 per $454 \mathrm{~kg}$ of dumped tomatoes. Among all detected elements, the greatest increase was observed for $\mathrm{Cu}$, whose concentrations increased from $0.01 \mathrm{mg} \cdot \mathrm{L}^{-1}$ in municipal water to $1.9-2.2$ $\mathrm{mg} \cdot \mathrm{L}^{-1}$ in the final wastewater. This concentration is greater than the threshold limit of $0.03 \mathrm{mg} \mathrm{Cu} \cdot \mathrm{L}^{-1}$ for surface water discharge and $0.5 \mathrm{mg} \mathrm{Cu} \cdot \mathrm{L}^{-1}$ for irrigation water use [7]. Whereas concentrations of $\mathrm{Fe}$ and $\mathrm{Zn}$ were less than the threshold limits of $1 \mathrm{mg} \cdot \mathrm{L}^{-1}$ for irrigation water. Therefore, wastewater may need to be treated to remove $\mathrm{Cu}$ before discharging into city sewers. Alterna- tively wastewater can be blended with higher-quality water to reduce $\mathrm{Cu}$ concentrations.

Concentrations of $\mathrm{P}$ in the wastewater (PKG 1:5.7 $\mathrm{mg} \cdot \mathrm{L}^{-1}$; PKG 2:2.8 $\mathrm{mg} \cdot \mathrm{L}^{-1}$ ) were similar to that of $\mathrm{mu}-$ nicipal wastewater $\left(2.5-6.5 \mathrm{mg} \cdot \mathrm{L}^{-1}\right)$ [23] and potato processing wastewater $\left(3.4 \mathrm{mg} \cdot \mathrm{L}^{-1}\right)$ [24]; but were much lower than animal wastewaters such as dairy $\left(30 \mathrm{mg} \cdot \mathrm{L}^{-1}\right)$ and poultry (34 $\mathrm{mg} \cdot \mathrm{L}^{-1}$ ) lagoon wastewater [22] and swine lagoon wastewater $\left(61 \mathrm{mg} \cdot \mathrm{L}^{-1}\right)$ [4]. The higher concentrations of total $\mathrm{P}$ in the wastewater relative to the highest new surface water quality standard of $0.49 \mathrm{mg} \cdot \mathrm{L}^{-1}$ for Florida streams [25] suggests that packinghouse wastewater needs to be treated to remove $\mathrm{P}$ before it can be discharged into streams.

Increase in concentrations of $\mathrm{Ca}, \mathrm{Mg}, \mathrm{K}, \mathrm{Fe}$, and $\mathrm{Zn}$ wastewater (see Figures 3-4) do not present constraints on wastewater reuse. As a comparison, Ca concentrations in the wastewater $\left(55-59 \mathrm{mg} \cdot \mathrm{L}^{-1}\right.$ ) were similar to swine lagoon wastewater $\left(51 \mathrm{mg} \cdot \mathrm{L}^{-1}\right)$, but were much greater than municipal wastewater $\left(4 \mathrm{mg} \cdot \mathrm{L}^{-1}\right)[4,26]$. Similarly, $\mathrm{K}$ concentration in packinghouse wastewater (24 - 49 $\left.\mathrm{mg} \cdot \mathrm{L}^{-1}\right)$ was lower than the swine $\left(614 \mathrm{mg} \cdot \mathrm{L}^{-1}\right)$, dairy $\left(178 \mathrm{mg} \cdot \mathrm{L}^{-1}\right)$ and poultry $\left(1244 \mathrm{mg} \cdot \mathrm{L}^{-1}\right)$ lagoon wastewater $[4,22]$. Concentrations of $\mathrm{Zn}$ in packinghouse wastewater $\left(0.1-0.3 \mathrm{mg} \cdot \mathrm{L}^{-1}\right)$ were only slightly lower than animal manure wastewater $\left(0.4-0.6 \mathrm{mg} \cdot \mathrm{L}^{-1}\right)$ [22]. The tremendous variability in wastewater from different sources highlights the impact of internal and external sources in elevating concentrations of chemical constituents in different wastewaters.

To comply with the surface water discharge standards for $\mathrm{P}$ and $\mathrm{Cu}$, one potential option might be to treat wastewater with chemical amendments (alum, ferric chloride, lime) to remove $\mathrm{P}$ and $\mathrm{Cu}$ from the wastewater $[27,28]$. Another option could be to use wastewater for land irrigation in frequent but small application rates that do not promote leaching. Our recent study [29] found that if packinghouse wastewater is land applied at up to 1.68 $\mathrm{cm} \cdot$ day $^{-1}$ or $168,000 \mathrm{~L} \cdot \mathrm{ha}^{-1} \cdot \mathrm{day}^{-1}$, the risk of $\mathrm{P}$ and cation ( $\mathrm{Na}, \mathrm{Ca}, \mathrm{Mg}, \mathrm{K}$ ) leaching to groundwater is minimal. In these wastewater applied sites, a minimum unsaturated depth of $45 \mathrm{~cm}$ to the water table has been recommended to avoid ponding at the surface and maintain aerobic conditions in the root zone of the cover crops [30].

\section{Conclusions}

Results suggest that $\mathrm{EC}$ and $\mathrm{Cl}$ were elevated in the wastewater because of the use of chlorine sanitizers in the dump tanks. This may pose moderate to strict restrictions for wastewater use as irrigation water for crops such as beans, carrot, okra, onion, and strawberry [31]. The concentrations of wastewater constituents were rela- 
tively higher in PKG 1 than PKG 2, which were mainly due to greater contact time of small-sized tomatoes (having greater surface area) with dump tank water in PKG 1. Among all elements, $\mathrm{P}$ was above the total $\mathrm{P}$ standard of $0.49 \mathrm{mg} \cdot \mathrm{L}^{-1}$ for surface water discharge in Florida streams. Concentrations of $\mathrm{Fe}$ and $\mathrm{Zn}$ were less than the threshold value $\left(1 \mathrm{mg} \cdot \mathrm{L}^{-1}\right)$ for irrigation water suitability in agriculture [20]. In the current study, washing of tomatoes resulted in increased concentrations of all chemical constituents in the wastewater. This suggests that the $\mathrm{P}$ and $\mathrm{Cu}$ residues (from pesticides, insecticides, and/or foliar-applied micronutrients) originated from the fieldharvested tomatoes may be the likely sources of $\mathrm{P}$ and $\mathrm{Cu}$ in the wastewater. These results imply that wastewater needs to be treated for $\mathrm{P}$ and $\mathrm{Cu}$, if directly discharged to surface water bodies as their concentrations were above the critical values. Another attractive and feasible option is blending wastewater with higher-quality water (groundwater, municipal water) to dilute the concentrations of $\mathrm{P}$ and $\mathrm{Cu}$, which will also reduce $\mathrm{Cl}$ and EC. Future research should evaluate the scope of field best management practices to reduce $\mathrm{P}$ and $\mathrm{Cu}$ concentrations in the wastewater and develop a feasible and cost-effective treatment system to remove $\mathrm{P}$ and $\mathrm{Cu}$ from wastewater for economic and environmental sustainability of tomato industry in Florida.

\section{Acknowledgements}

Funding for this research was provided by U.S. Environmental Protection Agency (X9-95400608-0). We thank the Florida Tomato Committee and tomato packinghouse personnel for their cooperation and support.

\section{REFERENCES}

[1] FDEP, "General Facts and Statistics about Wastewater in Florida,” 12 June 2011. http://www.dep.state.fl.us/water/wastewater/facts.htm

[2] G. A. O’Connor, H. A. Elliott and R. K. Bastian, "Degraded Water Reuse: An Overview,” Journal of Environmental Quality, Vol. 37, Suppl. 5, 2008, pp. S157S168.

[3] California League of Food Processing, "Manual of Good Practice for Land Application of Food Processing/Rinse Water," Davis, CA, 2007.

[4] A. A. Szogi and M. B. Vanotti, "Removal of Phosphorus from Livestock Effluents,” Journal of Environmental Quality, Vol. 38, No. 2, 2009, pp. 576-586. doi:10.2134/jeq2007.0641

[5] G. Firfilionis, et al., "The Removal of Trace Metals at the Wastewater Treatment Plant of Psyttalia,” Mediterranean Marine Science, Vol. 5/1, 2004, pp. 71-81.

[6] Florida Tomato Committee, "Options for Utilization of Tomato Packinghouse Solid Waste and Water,” In: Critical Issues in Tomato Production in Florida-A Special
Research Report, Florida Tomato Committee and University of Florida/IFAS, 2007.

[7] Florida Administrative Weekly, "Florida Administrative Weekly and Florida Administrative Code 62-302.530," 2006.

[8] FDEP, "Water Rules by Program Area: Wastewater,” 12 June 2011, Cited 16 August 2010.

http://www.dep.state.fl.us/water/rulesprog.htm\#ww

[9] K. L. Rule, et al., "Diffuse Sources of Heavy Metals Entering an Urban Wastewater Catchment," Chemosphere, Vol. 63, No. 1, 2006, pp. 64-72. doi:10.1016/j.chemosphere.2005.07.052

[10] P. Crawford, et al., "Corrosion of a Stainless Steel Chemical Hood,” Engineering Failure Analysis, Vol. 5, No. 1, 1998, pp. 53-56. doi:10.1016/S1350-6307(97)00032-0

[11] T. Eliades, et al., "Characterization and Cytotoxicity of Ions Released from Stainless Steel and Nickel-Titanium Orthodontic Alloys,” American Journal of Orthodontics and Dentofacial Orthopedics, Vol. 125, No. 1, 2004, pp. 24-29. doi:10.1016/j.ajodo.2003.09.009

[12] H. F. Bohner and R. L. Bradley, "Corrosivity of Chlorine Dioxide Used as Sanitizer in Ultrafiltration Systems," Journal of Dairy Science, Vol. 74, No. 10, 1991, pp. 3348-3352. doi:10.3168/jds.S0022-0302(91)78523-8

[13] S. M. Olson and E. Simonne, "Vegetable Production Handbook for Florida," IFAS/Extension, University of Florida, 2009, pp. 291-313.

[14] J. A. Bartz, S. A. Sargent and M. Mahovic, "Guide to Identifying and Controlling Post Harvest Tomato Diseases in Florida,” IFAS/extension HS 866, University of Florida, 2009.

[15] R. Maxfield and B. Mindak, "Environmental Protection Agency Method 200.7 Trace Metals by ICP (Inductively Coupled Plasma)," US Environmental Protection Agency, Washington, DC, EPA/600/4-85/051 (NTIS PB85248656), 1985, Cited 12 June 2011. http://cfpub.epa.gov/si/si_public_record_Report.cfm?dirE ntryID=47183

[16] North Carolina Agricultural Research Service, "Notice of Naming and Release of 'Plum Crimson' Hybrid Tomato," 2002, Cited 13 April 2010.

http://www.ces.ncsu.edu/fletcher/programs/tomato/releas es/release-notices/release-Plum-Crimson.pdf

[17] J. W. Scott, S. M. Olson and J. A. Bartz, "Tribeca' Hybrid Tomato; Fla. 8124C and Fla. 8249 Breeding Lines," HortScience, Vol. 44, No. 2, 2009, pp. 471-473.

[18] J. A. Bonilla and G. S. Toor, "Assessment of Microbes in Tomato Packinghouses," Florida Tomato Institute Proceedings, 12 June 2011, pp. 8-10. http://www.hos.ufl.edu/vegetarian/09/Sep/Tomato\%20Pr oceedings\%202009.pdf

[19] T. J. Stevens and R. L. Kilmer, “A Descriptive and Comparative Analysis of Pesticide Residues Found in Florida Tomatoes and Strawberries,” IFAS/Ext BUL331, University of Florida, 2009.

[20] R. S. Ayers and D. W. Westcot, "Water Quality for Agriculture,” FAO Irrigation and Drainage Paper 29 Rev.1, 
Rome, 1989.

[21] M. Y. Fukayama, et al., "Reactions of Aqueous Chlorine and Chlorine Dioxide with Model Food Compounds," Environmental Health Perspectives, Vol. 69, 1986, pp. 267-274. doi:10.1289/ehp.8669267

[22] S. A. Bradford, et al., "Reuse of Concentrated Animal Feeding Operation Wastewater on Agricultural Lands," Journal of Environmental Quality, Vol. 37, 2008, pp. S97-S115. doi:10.2134/jeq2007.0393

[23] H. Monclús, et al., "Biological Nutrient Removal in an MBR Treating Municipal Wastewater with Special Focus on Biological Phosphorus Removal,” Bioresource Technology, Vol. 101, No. 11, 2010, pp. 3984-3991. doi:10.1016/j.biortech.2010.01.038

[24] F. Zvomuya, C. J. Rosen and S. C. Gupta, "Phosphorus Sequestration by Chemical Amendments to Reduce Leaching from Wastewater Applications," Journal of Environmental Quality, Vol. 35, No. 1, 2006, pp. 207-215. doi:10.2134/jeq2005.0172

[25] EPA, “Technical Support Document for U.S. EPA's Final Rule for Numeric Criteria for Nitrogen/Phosphorus Pollution in Florida's Inland Surface Fresh Waters,” 2010. http://water.epa.gov/lawsregs/rulesregs/upload/floridatsd1 .pdf

[26] T. W. Biggs and B. Jiang, "Soil Salinity and Exchange- able Cations in a Wastewater Irrigated Area, India,” Journal of Environmental Quality, Vol. 38, No. 3, 2009, pp. 887-896. doi:10.2134/jeq2008.0247

[27] J. M. Ebeling, C. F. Welsh and K. L. Rishel, "Performance Evaluation of an Inclined Belt Filter Using Coagulation/Flocculation Aids for the Removal of Suspended Solids and Phosphorus from Microscreen Backwash Effluent," Aquacultural Engineering, Vol. 35, No. 1, 2006, pp. 61-77. doi:10.1016/j.aquaeng.2005.08.006

[28] C. Kang, et al., "Process Development for the Removal of Copper from Wastewater Using Ferric/Limestone Treatment," Korean Journal of Chemical Engineering, Vol. 20, No. 3, 2003, pp. 482-486. doi:10.1007/BF02705552

[29] M. K. Chahal, et al., "Effect of Tomato Packinghouse Wastewater Properties on Phosphorus and Cation Leaching in a Spodosol,” Journal of Environmental Quality, Vol. 40, 2011, pp. 999-1009. doi:10.2134/jeq2010.0369

[30] FDEP, "Permit for Disposal of Tomato Washwater," Industrial Wastewater General/Generic Permits, 2009, Cited 16 August 2010. http://www.dep.state.fl.us/legal/Rules/wastewater/62-660. pdf

[31] D. Z. Haman, "Irrigating with High Salinity Water," IFAS/Extension BUL322, University of Florida, Floria, 2009. 